Nota

\title{
DIAGNOSIS AND RECOMMENDATION INTEGRATED SYSTEM (DRIS) OF SOYBEAN SEED OIL CONTENT ${ }^{(1)}$
}

\author{
Alfredo Castamann ${ }^{(2)}$, Pedro Alexandre Varella Escosteguy ${ }^{(3)}$, Diego Berres $^{(4)}$ \& Silas Zanella ${ }^{(4)}$
}

\begin{abstract}
SUMMARY
The Diagnosis and Recommendation Integrated System (DRIS) can improve interpretations of leaf analysis to determi nethe nutrient status. Diagnoses by this method require DRIS norms, which are however not known for oil content of soybean seeds. The aims of this study were to establish and test the DRIS method for oil content of soybean seed (maturity group II cultivars). Soybean leaves (207 samples) in the full flowering stage were analyzed for macro and micro-nutrients, and the DRIS was applied to assess the relationship between nutrient ratios and the seed oil content. Samples from experimental and farm field sites of the southernmost Brazilian state Rio Grande do Sul $\left(28^{\circ}-29^{\circ}\right.$ southern latitude; $52^{\circ}$. $53^{\circ}$ western longitude) were assessed in two growing seasons (2007/2008 and 2008/ 2009). The DRIS norms related to seed oil content differed between the studied years. A unique DRIS norm was established for seed oil content higher than $18.68 \%$ based on data of the 2007/2008 growing season. Higher DRIS indices of B, $\mathrm{Ca}, \mathrm{Mg}$ and $\mathrm{S}$ were associated with a higher oil content, while the opposite was found for $K, N$ and $P$. The DRIS can be used to evaluate the leaf nutrient status of soybean to improve the seed oil content of the crop.
\end{abstract}

Index terms: nutritional diagnosis, plant nutrition, nutritional balance, Glycine $\max ($ L.) Merrill.

(1) Part of the thesis of the first author presented to the Graduate Program in Agronomy, University of Passo Fundo (UPF). Financially supported by FAPERGS, Received for publication in November 30, 2011 and approved in October 17, 2012.

(2) Adjunct Professor, School of Agronomy, Federal University of Fronteira Sul. Av. Dom J oão Hoffmann, 313, Fátima. CEP 99700-000 Erechim (RS), Brasil. E-mail: castamann@terra.com.br

(3) Professor, UPF. Caixa Postal 611. CEP 99001-970 Passo Fundo (RS). E-mail: escosteguy@upf.br

(4) Undergraduate students, School of Agronomy, FAMV/UPF. Fellow students at UPF and FAPERGS, respectively. E-mail: diegoberres@hotmail.com; silaszanella@gmail.com 


\title{
RESUMO:SISTEMA INTEGRADO DE DIAGNOSE E RECOMENDAÇÃO (DRIS) PARA DIAGNÓSTICO DO TEOR DE ÓLEO EM GRÃO DE SOJ A
}

\begin{abstract}
O Sistema I ntegrado deDiagnoseeRecomendação(DRIS) podemel horar a interpretação da análise foliar, contribuindo com a avaliação do estado nutricional. Para diagnósticos obtidos comessemétodo, éimprescindível queas normas DRIS sejam previamenteestabelecidas, o queainda não foi efetuado para o teor deóleo do grão desoja. Os objetivos destetrabal ho foram estabelecer as normas DRIS eavaliar essemétodo, em relação ao teor deól eo do grão de soja (cultivares do grupo II de maturação). Foram determi nados os teores de macro e de micronutrientes de 207 amostras de fol has dessa cultura, col etadas no estádio do pleno florescimento, eavaliada a rel ação entrea razão dos nutrientes eoteor deól eo no grão usando o método DRIS. As amostras foram obti das em parcel as experimentais eem lavouras comerciais do Estado do Rio Grande do Sul ( $28^{\circ} \mathrm{e} 29^{\circ}$ delatitudesul; e $52^{\circ}$ e $53^{\circ}$ delongitudeoeste), nas safras 2007/ 2008 e 2008/ 2009. As normas DRIS relacionadas com o teor de ól eo do grão diferiram entreos anos agrícol as. F oi estabel ecida uma única norma DRIS para o teor deóleo do grão mai or que $18,68 \%$, com os resultados do banco de dados do ano $2007 / 2008$. O acréscimo dos val ores dos índices DRIS deB, Ca, Mg eS foi acompanhado do maior teor de óleo, ocorrendo o contrári o com os índices deK, N eP. O DRIS podeser usado para avaliar o status denutrientes defol ha desoja, com o objetivo demel horar o teor deóleo do grão dessa cultura.
\end{abstract}

Termos deindexação: diagnosenutricional, nutrição vegetal, equilíbrio nutricional, Glycine $\max ($ L.) Merrill.

\section{INTRODUCTION}

Soybean (Glycine max (L.) Merrill) is the major source of oil and protein in theinternational market. Theeconomic importance of this crop is mostly dueto the high oil and protein concentrations in soybean seed (Câmara et al., 2004). Previous studies related to oil and protein content in soybean seed suggested high variations across cultivars (Maestri et al., 1998; Rangel et al., 2004, 2007) and across environmental conditions and factors (Bachlava \& Cardinal, 2009; Carrera et al., 2009; Proulx \& Naeve, 2009), mainly during reproductive growth (Wilson, 2004).

The plant nutritional status varies according to the factors that influence the soil availability of nutrients (Taiz \& Zeiger, 2009). Themost widely used method for the diagnosis of plant nutritional status is based on critical leaf nutrient content. However, this method does not allow assessing the relationship among nutrients. On the other hand, the Diagnosis and Recommendation I ntegrated System (DRIS) has been proposed as an alternativeto critical leaf nutrient content. DRIS can be used toassess theinteraction of nutrient leaf analysis (Urano et al., 2007; F arnezi et al., 2009), and most studies with this approach focus on nutrient balance, fertilization practices and crop yield (U rano et al., 2007; Bailey et al., 2009; F arnezi et al., 2009). Besides yield, nutrient imbalances or deficiencies may affect the oil content of the seeds. H owever, few studies have been conducted to assess the effect of nutrient balance on oil content of soybean seeds (Seguin \& Zheng, 2006).

Although DRIS has been proposed as a universal method (Beaufils, 1973), recent studies have pointed out that the establishment of regional DRIS norms or standards enables more accurate diagnoses of the plant nutritional status (Silva et al ., 2005; Farnezi et al., 2009). DRIS has proved to be a promising method for the calibration of optimal nutrient concentrations in soybean (Urano et al., 2007).

DRIS norms for soybean have not been established for thestate of RS, thus restricting the application of this method. Also, the scientific literature does not discuss DRI S norms based on oil concentration as a response variable. Moreover, other methods for the interpretation of leaf analysis have not been investigated for the improvement of the nutritional status of soybean given theincrease in seed oil content. The aims of this study were to establish and test the DRIS method for oil content of soybean seeds.

\section{MATE RIAL AND METHODS}

\section{Location}

Soybean plants assessed for the development of DRIS norms were grown in the experimental area of the University of Passo Fundo (UPF), whereas the plants assessed for the val idation of thesenorms were from farm fields of the Planalto Médio Region of the State of Rio Grande do Sul $\left(28^{\circ}\right.$ - $29^{\circ}$ southern latitude; $52^{\circ}-53^{\circ}$ western longitude), in the 2007/2008 and $2008 / 2009$ growing seasons. Theregional climatewas classified according to Köppen as Cfa characterized as subtropical wet, without a clearly defined dry season, average temperature higher than $22{ }^{\circ} \mathrm{C}$ in the hottest month (Cunha, 1997), average annual 
temperature of $17.5^{\circ} \mathrm{C}$ and average annual rainfall of 1,787.8 $\mathrm{mm}$ (Embrapa Trigo, 2008). The assessed plants were not irrigated. The soils of the assessed areas were a Dystroferric Red Nitosol and a Humic Dystrophic Red Latosol, These soils with no physical or nutritional constraints had been under no-tillage for over 10 years. The variability in soil fertility across experimental plots and farm fiel ds was a prerequisite for this research, for investigating differences in the nutritional status of leaf samples.

\section{Database, sampling protocol and analysis}

Two data sets (2007/2008 and 2008/2009 growing seasons) were constructed, both to establ ish theDRIS norms and to test them. To establish the norms, 84 (2007/2008) or 94 (2008/2009) samples wereanalyzed, while to test theDRIS method, 15 (2007/2008) or 14 (2008/2009) samples wereassessed. The cultivars BRS 243 RR (2007/2008) and F undacep 55 RR (2008/2009), both belonging to maturity group II, were used to establish DRIS norms. The soybean cultivars 6445 RR, 6001 RR, Apolo RR, Fundacep 53 RR, and Fundacep 55 RR were evaluated in the farm fields, all of maturity group II.

Rainfed crops were managed in compliance with the recommended cultural practices. In the experimental area, plots (3.5 $66 \mathrm{~m})$, and black oats (Avena strigosa Schreb) was used as cover crop prior to soybean in both growing season. The sampled farm fields covered approximately 1 ha. Leaf samples consisted of 30 recently matured trifoliateleaves, with petioles (Farias et al., 2007), randomly coll lected during full flowering (R2 stage) (Neumaier et al., 2000). The total concentrations of N, P, K, Ca, Mg, S, B, Zn, Cu, $\mathrm{Mn}$, and Fein the leaf tissue were determined by the method described by Tedesco et al. (1995).

Seed samples were obtained from the whole area of experimental plots and farm fields with a combine harvester, to determine the oil content by nearinfrared reflectancespectroscopy (NIRS) (van Kempem \& J ackson, 1996). This method had been calibrated previously by determining the oil content of 120 soybean seed samples using the Soxl et method (AOAC, 1995) and hexane as solvent. The results were expressed as percentage of dry mass $\left(65^{\circ} \mathrm{C}\right)$.

\section{DRIS establishment}

Thetotal leaf-nutrient content data were processed by software devel oped at UPF, generating the DRIS norms and nutrient indices. One of the binary relations of nutrients of direct or inverse order was used to computetheDRIS indices. Thelargest varianceratio obtained between the high- and low-yielding subpopulations adopted for the selection of direct (A) $B$ ) or inverse $(B / A)$ nutrient relations was used as criterion. From thebinary relations, DRIS indices (IA) may then be calculated for nutrients, using the generalized equations proposed by Beaufils (1973), where $\mathrm{n}$ is the number of relations of direct order, $\mathrm{k}$ the sensitivity constant, CV the coefficient of variation and $m$ is the number of relations of inverse order:

$$
\begin{aligned}
& I_{A}=\sum_{i=1}^{n}\left[f\left(\frac{A}{B}\right)_{1} \frac{K}{C V} \times 100+f\left(\frac{A}{C}\right)_{2} \frac{K}{C V} \times 100+\ldots\right. \\
& \left.+f\left(\frac{A}{N}\right)_{n} \frac{K}{C V} \times 100\right]-\sum_{i=1}^{m}\left[f\left(\frac{B}{A}\right)_{1} \frac{K}{C V} \times 100+\right. \\
& \left.f\left(\frac{C}{A}\right)_{2} \frac{K}{C V} \times 100+\ldots+f\left(\frac{N}{A}\right)_{m} \frac{K}{C V} \times 100\right] / n+m
\end{aligned}
$$

After obtaining theDRIS indices for thenutrients, the nutritional balanceindex (NBI) of the sample was calculated. This index consists of the sum of all DRIS indices in absolutevalues, as described by Wadt (1996):

$$
\mathrm{NBI}=\left|\mathrm{I}_{\mathrm{A}}\right|+\left|\mathrm{I}_{\mathrm{B}}\right|+\left|\mathrm{I}_{\mathrm{C}}\right|+\ldots+\left|\mathrm{I}_{\mathrm{N}}\right|
$$

The mean NBI (mNBI) was calculated by dividing the NBI by the number of preliminary indices (per nutrient) used in the calculation (Wadt, 1996):

$$
\mathrm{NBI}_{\mathrm{m}}=\frac{\left|\mathrm{I}_{\mathrm{A}}\right|+\left|\mathrm{I}_{\mathrm{B}}\right|+\left|\mathrm{I}_{\mathrm{C}}\right|+\ldots+\left|\mathrm{I}_{\mathrm{N}}\right|}{\mathrm{n}}
$$

The DRIS norms were obtained from the mean values of the existing binary relations between the analyzed nutrients and the standard deviation(s) (Mal avolta, 2006). The DRIS indices wereinterpreted by dassifying thenutrients according to their potential responseto fertilization, as proposed by Wadt (1996). The classes of positive, negative and zero responses were designated as limiting factors due to deficiency, excess, and null (without limitation), respectively (Silva et al., 2005).

Thereferencesubpopulations consisted of samples with higher oil contents than the mean-plus-one standard deviation $(18.68 ; 21.38$ and $20.62 \%$, in the $2007 / 2008$ and $2008 / 2009$ growing seasons and for the combined data set, respectively). These mean values can be considered adequatesince, in general, soybean has a seed oil content of $11.29-32.45 \%$ (Al brecht et al., 2008). Thenumber of referencepopulation samples was 13 in the harvest of 2008; 24 in the harvest of 2009; and 35 in the combined data set. Thesenumbers of samples are higher than the minimum of $10 \%$ of samples from the database, which is considered adequate by Letzsch \& Sumner (1984). Different samples were evaluated in each year and for each experimental plot.

\section{Statistical analysis}

Normal distribution and other descriptive statistical parameters were cal culated by theSisvar software (Ferreira, 2000). The t test was used to compare the contents of leaf nutrients and seed oil, obtained from the 2008 and 2009 harvests and from their combined data set. The norms were analyzed according to the DRIS indices, as proposed by Wadt 
(1996), using the chi-square test, in addition to the correlation between oil content (dependent variable) and NBI, using Excel (Microsoft Office ${ }^{\circledR 2007)}$.

To assess the nutritional status diagnosed with the proposed norms, plants from farm fields ( 14 and 15 samples, in 2008 and 2009, respectively) were evaluated by using the DRIS norms.

\section{RESULTS AND DISCUSSION}

Ranges for nutrient concentration in leaves and seed oil content of the reference subpopulations (oil content >18.71, 21.36 and 21.05\% in 2007/2008 and 2008/2009 and in the combined data set, respectively) across growing seasons are shown in table 1 . The observed ranges in our study ( $\mathrm{N} 32.8-59.4 \mathrm{~g} \mathrm{~kg}^{-1}$; $\mathrm{P}$ 1.2-5.6 $\mathrm{g} \mathrm{kg}^{-1}$; K 10.2-46.7 $\mathrm{g} \mathrm{kg}^{-1}$; Ca $5.0-12.7 \mathrm{~g} \mathrm{~kg}^{-1}$; $\mathrm{Mg} 1.8-5.0 \mathrm{~g} \mathrm{~kg}^{-1}$; $\mathrm{S} 0.8-3.5 \mathrm{~g} \mathrm{~kg}^{-1}$; Zn $19.34-75.61 \mathrm{mg}$ $\mathrm{kg}^{-1}$; Cu 3.81-13.72 $\mathrm{mg} \mathrm{kg}^{-1}$; Mn 26.74-35.15 $\mathrm{mg} \mathrm{kg}^{-1}$; Fe 30.19-179.38 $\mathrm{mg} \mathrm{kg}^{-1}$; B 14.48-52.47 $\mathrm{mg} \mathrm{kg}^{-1}$ and oil 16.27-22.47\%) weresimilar tothe range reported elsewhere in studies on soybean nutrient status (Urano et al., 2007) or on seed oil (Maestri et al., 1998; Bonato et al., 2000; Chung et al., 2003; Fasoula et al., 2004; Albrecht et al., 2008; Bellal oui et al., 2009). On the other hand, the results were lower than the oil content range of 17.2 to $28.5 \%$ reported by Dardanelli et al. (2006), since in this last study some of theanalyzed cultivars were from soybean maturity groups with higher oil content yield.

The seed oil content variability was lower in samples from theexperimental area than from thefield sites, mainly in 2007/2008 ( $s=0.66$; CV $=3.67 \%$ ) (Table 1), as indicated by the DRIS norms. In this year, the mean oil content (18.01\%) was lower than that of $2008 / 2009$ (20.17\%) and the mean values of these two years (19.39\%). This year effect was associated to rainfall (862 $\mathrm{mm}$ in 2007/2008 and $400 \mathrm{~mm}$ in 2008/2009), as well-described in studies on the effect of water availability on soybean (Kravchenko \& Bullock, 2002; Albrecht et al., 2008;

Table 1. Descri ptive statistics of leaf nutrient contents in soybean (R2 stage) with high(1) oil content, based on data of the $2007 / 08$ and $2008 / 09$ growing seasons and the means of these years

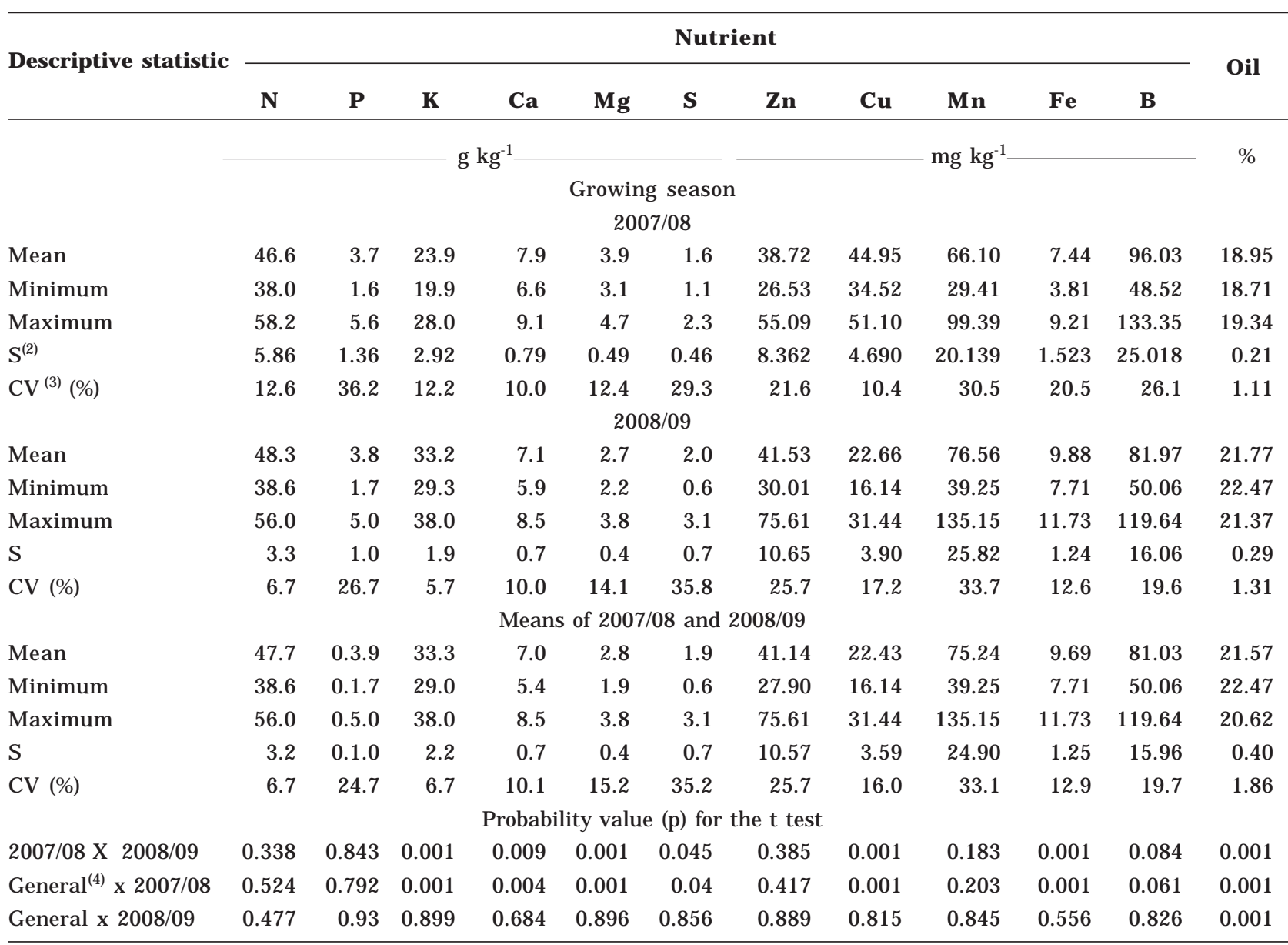

(1) Oil content $>18.71,21.36$ and $21.05 \%$ in 2007/08, 2008/09 growing seasons and for the combined set of these years, respectively. (2) Standard deviation. (3) Coefficient of variation. (4) Samples of 2007/08 and 2008/09 growing seasons. 
Naeve \& Huerd, 2008; Bachlava \& Cardinal, 2009; Proulx \& Naeve, 2009).

The correlation between seed oil content and NBI varied with theanalyzed database. In 2007/2008, this correlation was negative $(r=0.647 ; p=0.002)$ and positive in 2008/2009 ( $r=0.628 ; p=0.002)$ as well as for thetwo-year data set $(r=0.630 ; p=0.002)$. Therefore, the DRIS norms of the second year and for the combined set of both years did not result in an appropriatenutritional diagnosis, unlikethenormfor $2007 / 2008$. These results suggest that a unique norm enabled an appropriate diagnosis of oil content of soybean seeds. In this way, the norms for 2008/2009 and for the combined set of both years were not shown in the paper, whereas the DRIS norm of the 2007/ 2008 growing season is displayed in table 2 .

The difference between the norms may be attributed to the cultivar or environmental effects. Sincethecultivars used in the study region vary from

Table 2. Mean and standard deviation (s) of binary rati os between leaf nutrient contents ( $R 2$ stage) in soybean plants for the subpopulation with high(1) seed oil content (DRIS Norms). 2007/08 growing season

\begin{tabular}{lrrlrr}
\hline Norm & Mean & \multicolumn{1}{c}{ s } & Norm & Mean & \multicolumn{1}{c}{ s } \\
\hline $\mathrm{B} / \mathrm{S}$ & 308.719 & 98.292 & $\mathrm{~K} / \mathrm{B}$ & 0.054 & 0.009 \\
$\mathrm{~B} / \mathrm{Zn}$ & 1.178 & 0.184 & $\mathrm{~K} / \mathrm{Mn}$ & 0.040 & 0.013 \\
$\mathrm{Ca} / \mathrm{B}$ & 0.018 & 0.002 & $\mathrm{~K} / \mathrm{P}$ & 7.420 & 3.613 \\
$\mathrm{Ca} / \mathrm{Cu}$ & 0.110 & 0.031 & $\mathrm{~K} / \mathrm{S}$ & 16.366 & 5.159 \\
$\mathrm{Ca} / \mathrm{K}$ & 0.338 & 0.060 & $\mathrm{~K} / \mathrm{Zn}$ & 0.064 & 0.017 \\
$\mathrm{Ca} / \mathrm{N}$ & 0.170 & 0.031 & $\mathrm{Mg} / \mathrm{B}$ & 0.009 & 0.0017 \\
$\mathrm{Ca} / \mathrm{P}$ & 2.498 & 1.216 & $\mathrm{Mg} / \mathrm{Ca}$ & 0.498 & 0.059 \\
$\mathrm{Ca} / \mathrm{S}$ & 5.542 & 1.912 & $\mathrm{Mg} / \mathrm{K}$ & 0.166 & 0.022 \\
$\mathrm{Ca} / \mathrm{Zn}$ & 0.021 & 0.004 & $\mathrm{Mg} / \mathrm{Mn}$ & 0.007 & 0.0026 \\
$\mathrm{Cu} / \mathrm{B}$ & 0.173 & 0.049 & $\mathrm{Mg} / \mathrm{N}$ & 0.083 & 0.011 \\
$\mathrm{Cu} / \mathrm{K}$ & 3.244 & 0.747 & $\mathrm{Mg} / \mathrm{P}$ & 1.252 & 0.674 \\
$\mathrm{Cu} / \mathrm{Mg}$ & 19.784 & 5.212 & $\mathrm{Mg} / \mathrm{S}$ & 2.756 & 1.027 \\
$\mathrm{Cu} / \mathrm{Mn}$ & 0.127 & 0.046 & $\mathrm{Mg} / \mathrm{Zn}$ & 0.011 & 0.0027 \\
$\mathrm{Cu} / \mathrm{N}$ & 1.619 & 0.349 & $\mathrm{Mn} / \mathrm{B}$ & 1.448 & 0.342 \\
$\mathrm{Cu} / \mathrm{P}$ & 24.278 & 12.608 & $\mathrm{Mn} / \mathrm{Ca}$ & 82.755 & 23.813 \\
$\mathrm{Cu} / \mathrm{S}$ & 52.004 & 18.029 & $\mathrm{Mn} / \mathrm{S}$ & 454.738 & 200.579 \\
$\mathrm{Cu} / \mathrm{Zn}$ & 0.204 & 0.070 & $\mathrm{Mn} / \mathrm{Zn}$ & 1.694 & 0.454 \\
$\mathrm{Fe} / \mathrm{B}$ & 2.145 & 0.532 & $\mathrm{~N} / \mathrm{B}$ & 0.108 & 0.026 \\
$\mathrm{Fe} / \mathrm{Ca}$ & 121.732 & 34.911 & $\mathrm{~N} / \mathrm{K}$ & 2.000 & 0.245 \\
$\mathrm{Fe} / \mathrm{Cu}$ & 12.607 & 2.246 & $\mathrm{~N} / \mathrm{Mn}$ & 0.081 & 0.033 \\
$\mathrm{Fe} / \mathrm{K}$ & 40.508 & 10.596 & $\mathrm{~N} / \mathrm{P}$ & 15.060 & 8.208 \\
$\mathrm{Fe} / \mathrm{Mg}$ & 248.569 & 77.894 & $\mathrm{~N} / \mathrm{S}$ & 32.546 & 10.379 \\
$\mathrm{Fe} / \mathrm{Mn}$ & 1.592 & 0.673 & $\mathrm{~N} / \mathrm{Zn}$ & 0.128 & 0.039 \\
$\mathrm{Fe} / \mathrm{N}$ & 20.315 & 5.523 & $\mathrm{P} / \mathrm{B}$ & 0.009 & 0.0034 \\
$\mathrm{Fe} / \mathrm{P}$ & 300.165 & 149.397 & $\mathrm{P} / \mathrm{Mn}$ & 0.007 & 0.0037 \\
$\mathrm{Fe} / \mathrm{S}$ & 633.408 & 183.191 & $\mathrm{P} / \mathrm{Zn}$ & 0.010 & 0.0045 \\
$\mathrm{Fe} / \mathrm{Zn}$ & 2.550 & 0.855 & $\mathrm{~S} / \mathrm{P}$ & 0.459 & 0.166 \\
& & & $\mathrm{~S} / \mathrm{Zn}$ & 0.004 & 0.0020 \\
\hline $\mathrm{F}$ & & & & \\
& & & & & \\
& & & & &
\end{tabular}

(1) Oil content $>18.68 \% ; n=13$. year to year, because new cultivars are introduced and others are withdrawn, it is not simple to evaluate the consistency of results between years. However, all analyzed cultivars were from the same maturity group and the interest here was to eval uate the effect of weather variations, rather than of cultivars. In this way, theseresults permitted theanalysis of a different range of environmental conditions each year and the repeatability of the two studied years. Aside from the annual differences, the appropriate diagnosis found with DRIS norms for 2007/2008 may indicate that the nutritional status of cultivar BRS 243 RR, used in this year, is cl oser to farm field cultivars than the cultivar F undacep $55 \mathrm{RR}$, used to establish thenorms of the 2008/2009 growing season.

Sulfur was often present in the binary ratios found for suitable nutritional balance and high oil content (Table 2). This is due to the role S plays as a constituent of cystine, cysteine, and methionine, which are essential amino acids for the formation of plant proteins and biotin and thiamine, as well as of enzymes that synthesize essential substances for the plant (Dechem \& Nachtigall, 2007). Cysteine and methionine are precursors to coenzyme $A$ synthesis (Epstein \& Bloom, 2006; Marschner, 2012), which participate in Acetyl-CoA synthesis and in the first step of the biosynthetic pathway of fatty acids (Taiz $\&$ Zeiger, 2009). Then, it explains the importance of S in the nutrition of oil plants and likely explains the positive correlation between the higher DRIS indices for this nutrient and seed oil content (Table 5).

Thenutritional diagnoses of K, Mg, S and B differed between thenorms of thetwo growing seasons (Table

Table 3. Chi-square test with frequency of events interpreted according to the potential response to fertilization proposed by Wadt (1996), taking into account the DRIS indices of each nutrient, calculated using the proposed norms in different growing season

\begin{tabular}{cccc}
\hline & \multicolumn{3}{c}{ Growing season } \\
\cline { 2 - 4 } Nutrient & $\mathbf{2 0 0 7 / 0 8}$ & $\mathbf{2 0 0 7 / 0 8}$ & $\mathbf{2 0 0 8 / 0 9}$ \\
& $\mathbf{X}$ & $\mathbf{X}$ & $\mathbf{X}$ \\
\hline $\mathrm{N}$ & 0.355 & 0.682 & 0.659 \\
$\mathrm{P}$ & 0.445 & 0.445 & 1.000 \\
$\mathrm{~K}$ & 0.000 & 0.000 & 0.707 \\
$\mathrm{Ca}$ & 0.906 & 0.528 & 0.839 \\
$\mathrm{Mg}$ & 0.053 & 0.009 & 0.974 \\
$\mathrm{~S}$ & 0.000 & 0.000 & 0.236 \\
$\mathrm{Zn}$ & 0.108 & 0.126 & 0.610 \\
$\mathrm{~B}$ & 0.000 & 0.000 & 0.961 \\
$\mathrm{Mn}$ & 0.230 & 0.294 & 0.906 \\
$\mathrm{Cu}$ & 0.145 & 0.234 & 0.937 \\
$\mathrm{Fe}$ & 0.939 & 0.945 & 0.994 \\
\hline
\end{tabular}


3). On the other hand, the nutritional status of $N, P$, $\mathrm{Ca}, \mathrm{Zn}, \mathrm{Mn}, \mathrm{Cu}$, and $\mathrm{Fe}$ calculated using the norms from the two analyzed growing season was quite similar. The frequency values of potential response fertilization (Table4) corroborate the results obtained by the chi-square test (Table 3).

Thecorrelation coefficient values for seed oil content and DRIS indices were similar when calculated for thethree different norms (Table5). A correlation was found between these variables using the proposed norms, except for Feand M n concentrations. Seed oil content was positively correlated with the leaf contents of $\mathrm{B}, \mathrm{Ca}, \mathrm{Mg}$ and $\mathrm{S}$. The most negative correlation coefficients were observed for the DRIS indices of $\mathrm{Cu}$, $\mathrm{K}, \mathrm{N}, \mathrm{P}$, and Zn (Table 5).

The positive correlation found between seed oil content and $\mathrm{B}$ indices can be explained by the role this nutrient plays in the plants. Thesefunctions have not been sufficiently clarified yet (Taiz \& Zeiger, 2009), although this nutrient plays a role in water uptake and carbohydratemetabolism and, when its levels are low, sugars accumulate in plant tissues (Dechem \& Nachtigall, 2007). This latter effect reduces the formation of fatty acids by the plant (Taiz \& Zeiger, 2009) and, consequently, reduces seed oil content. Therefore, at appropriate B levels, the formation of fatty acids by the plant is adequate, enhancing the seed oil content.

The oil bodies consist of a mono phospholipid membrane, which could explain the positive correlation between Ca indices and seed oil content. Amongst the functions of $\mathrm{Ca}$ in plants, $\mathrm{Ca}$ binds proteins, known as annexins, and phospholipids. Annexins, among other functions, many of which are not fully known, participate in processes such as phospholipid metabolism (Epstein \& Bloom, 2006). Magnesium activates many enzymes, mainly phosphorylation enzymes, which are essential for photosynthesis, respiration, and synthesis reactions of organic compounds, e.g., of lipids (E pstein \& Bloom, 2006; Dechen \& N achtigall, 2007). Possibly, thehigher lipid synthesis explains the correlation observed between the DRIS index of Mgand oil content.

The negative correlation of $\mathrm{Cu}$ concentration with seed oil content in soybean ( $r=0.805$; Table 5 ) is not closely related to the role of this nutrient, as it does not participate in lipid synthesis in plants. Copper directly influences $\mathrm{N}_{2}$ fixation and, therefore, protein synthesis in leguminous plants (Dechem \& Nachtigall, 2006; Malavolta, 2006). Potassium, $\mathrm{P}$ and $\mathrm{N}$ are important for protein synthesis, and their concentrations are negatively correlated with oil content (Bonato et al., 2000; Bellaloui et al., 2009). This can be inferred from the negative correlation between DRIS indices of $\mathrm{N}$ and seed oil content, as shown by the data for the assessed years (-0.627; 0.589 and -0.596 ; in 2007/2008, 2008/2009 and the combined data of these growing seasons, respectively) (Table 5). Also, higher concentrations of K, P and N favored protein formation to the detriment of fatty

Table 4. F requency of potential responseto fertilization (PRF)(1) for soybean leaf samples (R2 stage) assessed with the DRIS norms obtained from seed oil content in different growing seasons

\begin{tabular}{|c|c|c|c|c|c|c|c|c|c|c|c|}
\hline PRF & B & $\mathrm{Ca}$ & $\mathbf{C u}$ & $\mathbf{F e}$ & $\mathbf{K}$ & $\mathbf{M g}$ & $M n$ & $\mathbf{N}$ & $\mathbf{P}$ & $\mathbf{S}$ & $\mathbf{Z n}$ \\
\hline \multicolumn{12}{|c|}{ Growing season } \\
\hline \multicolumn{12}{|c|}{ Norm for $2007 / 08$} \\
\hline Positive & 8 & 0 & 0 & 0 & 1 & 5 & 1 & 3 & 4 & 1 & 6 \\
\hline Low or null & 3 & 2 & 1 & 3 & 0 & 6 & 2 & 6 & 9 & 0 & 5 \\
\hline Null & 17 & 19 & 15 & 18 & 16 & 17 & 25 & 20 & 16 & 13 & 16 \\
\hline Negative or null & 1 & 8 & 9 & 3 & 7 & 1 & 1 & 0 & 0 & 0 & 2 \\
\hline Negative & 0 & 0 & 4 & 5 & 5 & 0 & 0 & 0 & 0 & 15 & 0 \\
\hline \multicolumn{12}{|c|}{ Norm for $2008 / 09$} \\
\hline Positive & 1 & 1 & 2 & 0 & 7 & 1 & 4 & 2 & 8 & 3 & 0 \\
\hline Low or null & 0 & 2 & 4 & 2 & 6 & 2 & 6 & 5 & 12 & 1 & 7 \\
\hline Null & 8 & 18 & 16 & 16 & 15 & 19 & 19 & 18 & 9 & 25 & 19 \\
\hline Negative or null & 6 & 8 & 3 & 4 & 1 & 6 & 0 & 2 & 0 & 0 & 2 \\
\hline Negative & 14 & 0 & 4 & 7 & 0 & 1 & 0 & 2 & 0 & 0 & 1 \\
\hline \multicolumn{12}{|c|}{ Norm for $2007 / 08$ and $2008 / 09$} \\
\hline Positive & 1 & 2 & 2 & 0 & 6 & 1 & 4 & 2 & 8 & 2 & 1 \\
\hline Low or null & 0 & 2 & 2 & 3 & 7 & 2 & 6 & 5 & 12 & 1 & 11 \\
\hline Null & 10 & 17 & 17 & 15 & 15 & 21 & 18 & 20 & 9 & 21 & 15 \\
\hline Negative or null & 4 & 7 & 3 & 4 & 0 & 4 & 1 & 2 & 0 & 5 & 1 \\
\hline Negative & 14 & 1 & 5 & 7 & 1 & 1 & 0 & 0 & 0 & 0 & 1 \\
\hline
\end{tabular}

(1) Wadt (1996). 
Table 5. Correlation of soybean seed oil content and DRIS values obtained in two consecutive growing seasons and for the combined set of it in samples collected from farm fields in the Plateau Region of Rio Grande do Sul

\begin{tabular}{|c|c|c|c|c|c|c|c|c|c|c|c|}
\hline & B & $\mathrm{Ca}$ & $\mathrm{Cu}$ & $\mathrm{Fe}$ & K & Mg & Mn & $\mathbf{N}$ & $\mathbf{P}$ & $\mathbf{S}$ & $\mathrm{Zn}$ \\
\hline \multicolumn{12}{|c|}{ Growing season } \\
\hline \multicolumn{12}{|c|}{$2007 / 08$} \\
\hline$r^{(1)}$ & 0.682 & 0.590 & -0.805 & 0.127 & -0.594 & 0.473 & 0.096 & -0.627 & -0.734 & 0.673 & -0.647 \\
\hline$t^{(2)}$ & 4.39 & 5.17 & -4.22 & 0.82 & -3.50 & 2.47 & 0.64 & -4.80 & -5.16 & 4.59 & -3.36 \\
\hline$p^{(3)}$ & 0.001 & 0.001 & 0.001 & 0.419 & 0.002 & 0.020 & 0.528 & 0.001 & 0.001 & 0.001 & 0.002 \\
\hline \multicolumn{12}{|c|}{ 2008/09 } \\
\hline$r^{(1)}$ & 0.681 & 0.628 & -0.777 & 0.155 & -0.518 & 0.501 & 0.145 & -0.589 & -0.737 & 0.660 & -0.618 \\
\hline$t^{(2)}$ & 4.83 & 4.19 & -6.41 & 0.82 & -3.15 & 3.01 & 0.76 & -3.79 & -5.67 & 4.56 & -4.08 \\
\hline$p^{(3)}$ & 0.001 & 0.001 & 0.001 & 0.421 & 0.004 & 0.006 & 0.452 & 0.001 & 0.001 & 0.001 & 0.001 \\
\hline \multicolumn{12}{|c|}{$2007 / 08$ and $2008 / 09$} \\
\hline$r^{(1)}$ & 0.691 & 0.626 & -0.788 & 0.188 & -0.520 & 0.493 & 0.150 & -0.596 & -0.726 & 0.678 & -0.614 \\
\hline$t^{(2)}$ & 4.96 & 4.17 & -6.66 & 1.00 & -3.17 & 2.95 & 0.79 & -3.85 & -5.48 & 4.80 & -4.04 \\
\hline$p^{(3)}$ & 0.001 & 0.001 & 0.001 & 0.328 & 0.004 & 0.007 & 0.437 & 0.001 & 0.001 & 0.001 & 0.001 \\
\hline
\end{tabular}

${ }^{(1)}$ Correlation coefficient; ${ }^{(2)}$ Calculated " $t$ "; ${ }^{(3)}$ Probability of calculated " $t$ " > tabulated " $\mathrm{t}$ " value.

acid synthesis, whose effect possibly explains the negativecorrelation between theDRIS indices of these nutrients and seed oil content. This also applies to the results obtained for $\mathrm{Zn}$, as this nutrient participates in protein synthesis by activating proteins in DNA transcription (E pstein \& Bloom, 2006).

\section{CONCLUSIONS}

1. The Diagnosis and Recommendation I ntegrated System can beused toevaluate the leaf nutrient status of soybean for breeding for the seed oil content of this crop.

2. A uniqueDRIS norm of soybean was established, of a seed oil content higher than $18.68 \%$, based on the database of the $2007 / 2008$ growing season.

\section{LITERATURE CITED}

ALBRECHT, L.P.; BRACCINI, A. DE L.E.; ÁVILA, M.R.; SUZUKI, L.S.; SCAPIM, C.A. \& BARBOSA, M.C. Teores de óleo, proteínas e produtividade de soja em função da antecipação da semeadura na região oeste do Paraná. Bragantia, 67:865-873, 2008.

ASSOCIATION OF OFFICIAL ANALYTICAL CHEMISTS AOAC. Methods official of analysis. 16.ed. Washington, 1995. 2000p.

BACHLAVA, E. \& CARDINAL, A.J . Correlation between temperature and oleic acid seed content in three segregating soybean populations. Crop Sci., 49:1328-1335, 2009.
BAILEY, J .S.; RAMAKRISHNA, A. \& KIRCHHOF, G. An evaluation of nutritional constraints on sweet potato (I pomea batatas) production in the central highlands of Papua New Guinea. Plant Soil, 319:97-105, 2009.

BEAUFILS, E.R. Diagnosis and recommendation integrated system (DRIS): A general scheme for experimentation and calibration based on principles develop from research in plant nutrition. Pietermaritzburg, University of Natal, 1973. 132p. (Soil Science Bulletin, 1)

BELLALOUI, N.; SMITH, J.R.; RAY, J.D. \& GILLEN, A.M. Effect of maturity on seed composition in the early soybean production system as measured on near-isogenic soybean lines. Crop Sci., 49:608-620, 2009.

BONATO, E.R.; BERTAGNOLLI,P.F.; LANGE, C.E.\& RUBIN, S.A. Teor de óleo e de proteína em genótipos de soja desenvolvidos após 1990. Pesq. Agropec. Bras., 35:23912398, 2000.

CÂMARA, G. M. S.; PIPOLO, A. E. \& SINCLAIR, T. R. Effects of temperature on oil and protein concentration in soybean seeds cultured in vitro. Ann. Appl. Biol. 144:7176, 2004.

CARRERA, C.; MARTÍNEZ, M.J .; DARDANELLI, J.J . \& BALZARINI, M. Water deficit effect on the relationship between temperature during the seed fill period and soybean seed oil and protein concentrations. Crop Sci., 49:990-998, 2009.

CUNHA, G.R. Meteorologia: Fatos \& mitos. Passo Fundo, Embrapa-CNPT, 1997. 268p.

CHUNG, J .; BABKA, H.L.; GRAEF, G.L.; STASWICK, P.E.; LEE, D.J .; CREGAN, P.B.; SHOEMAKER, R.C. \& SPECHT, J.E. The seed protein, oil, and yield QTL on linkage group I. Crop Sci., 43:1053-1067, 2003. 
DARDANELLI, J.M.; BALZARINI, M.J .; MARTÍNEZ, M.; CUNIBERTI，S.; RESNIK， S.; RAMUNDA, S.F.; HERRERO, R. \& BAIGORRI, H. Soybean maturity groups, environments and their interaction define megaenvironments for seed composition in Argentina. Crop Sci., 46:1939-1947, 2006.

DECHEM, A.R. \& NACHTIGALL, G.R. Micronutrientes. In: FERNANDES, M.S., ed. Nutrição mineral de plantas. Viçosa, MG, Sociedade Brasileira de Ciência do Solo, 2006. p. $327-354$

DECHEM, A.R. \& NACHTIGALL, G.R. Elementos requeridos à nutrição mineral de plantas. In: NOVAIS, R.F.; ALVAREZ V., V.A.; BARROS, N.F.; FONTES, R.L.F., CANTARUTTI, R.B. \& NEVES, J.C.L., eds. Fertilidade do solo. Viçosa, MG, Sociedade Brasileira de Ciência do Solo, 2007. p.91-132.

EMPRESA BRASILEIRA DE PESQUISA AGROPECUÁRIA EMBRAPA TRIGO. Normais climatológicas (1961-1990): Passo Fundo - RS. Disponível em: <http:// www.cnpt.embrapa.br/pesquisa/agromet/app/principal/ normais.php>. Acesso em 29 de ago. de 2009.

EPSTEIN, E. \& BLOOM, A.J. Nutrição mineral de plantas. 2.ed. Sunderland, Sinauer Associates, 2006. 403p.

FARIAS, J .R.B.; NEPOMUCENO, A.L. \& NEUMAIER, N. Ecofisiologia da soja. Londrina, Embrapa Soja, 2007. 9p. (Circular Técnica, 48)

FARNEZI, M.M.M.; SILVA, E.B. \& GUIMARÃES, P.T.G. Diagnose nutricional de cafeeiros da região do Alto J equitinhonha (MG): Normas DRIS e faixas críticas de nutrientes. R. Bras. Ci. Solo, 33:969-978, 2009.

FASOULA, V.A.; HARRIS, D.K. \& BOERMA, H.R. Validation of soybean QTL for protein, oil, and seed weight. Crop Sci., 44:1218-1225, 2004.

FERREIRA, D. F. Análises estatísticas por meio do Sisvar para Windows versão 4.0. In 45a Reunião Anual da Região Brasileira da Sociedade internacional de Biometria. UFSCar, São Carlos, SP, 2000. p.255-258.

KRAVCHENKO, A.N. \& BULLOCK, D.G. Spatial Variability of soybean quality data as a function of field topography:I . Spatial data analysis. Crop Sci., 42:804-815, 2002.

LETZSCH, W.S. \& SUMNER, M.E. Effect of population size and yield level in selection of diagnosis and recommendation integrated system (DRIS) norms. Commun. Soil Sci. Plant Anal., 15:997-1006, 1984.

MAESTRI, D.M.; LABUCKAS, D.O.; MERILES, J.M.; LAMARQUE, A.; ZYGADLO, J.A. \& GUZMA 'N, C.A. Seed composition of soybean cultivars evaluated in different environmental regions. J. Sci. Food Agric., 77:494-498, 1998.

MALAVOLTA, E. Manual de nutrição mineral de plantas. São Paulo, Agronômica Ceres, 2006. 638p.
MARSCHNER, H. Mineral nutrition of higher plants. 3.ed. San Diego, Academic Press, 2012. 695p.

NAEVE, S.L. \& HUERD, S.C. Year, region, and temperature effects on the quality of Minnesota's soybean. Agron. J ., 100:690-695, 2008.

NEUMAIER, N.; NEPOMUCENO, A.L. \& FARIAS, J.R.B. Estádios de desenvolvimento da cultura da soja. In: BONATO, E.R., ed. Estresses em soja. Passo Fundo, Embrapa Trigo, 2000. 254p.

PROULX, R.A. \& NAEVE, S.L. Pod removal, shade, and defoliation effects on soybean yield, protein, and oil. Agron. J ., 101:971-978, 2009.

RANGEL, M.A.S.; CAVALHEIRO, L.R.; CAVICHIOLLI, D. \& CARDOSO, P.C. Efeito do genótipo e do ambiente sobre os teores de óleo e proteína nos grãos de soja, em quatro ambientes da Região Sul de Mato Grosso do Sul, safra 2002/2003. Dourados, Embrapa Agropecuária Oeste, 2004. 20p. (Boletim de Pesquisa e Desenvolvimento, 17)

RANGEL, M.A.S.; MINUZZI , A.; BRACCINI , A.L.; SCAPIM, C.A. \& CARDOSO, P.C. Efeitos da interação genótipos $x$ ambientes no rendimento de grãos e nos teores de proteína de cultivares de soja. Acta Sci. Agron., 29:351-354, 2007.

SEGUIN, P. \& ZHENG, W. Potassium, phosphorus, sulfur, and boron fertilization effects on soybean isoflavone content and other seed characteristics. J. Plant Nutr., 29:681-69, 2006.

SILVA, G.G.C.; NEVES, J.C.L.; ALVAREZ V., V.H. \& LEITE, F.P. Avaliação da universalidade das normas DRIS, MDRIS e CND. R. Bras. Ci. Solo, 29:755-761, 2005.

TAIZ, L. \& ZEIGER, E. Fisiologia vegetal. 4.ed. Porto Alegre, Artmed, 2009. 719p.

TEDESCO, M.J .; GIANELLO, C.; BISSANI, C.A.; BOHNEN, H. \& VOLKWEISS, S.J . Análise de solo, plantas e outros materiais. 2.ed. Porto Alegre, Universidade Federal do Rio Grande do Sul, 1995. 174p. (Boletim Técnico, 5)

URANO, E.O.M.; KURIHARA, C.H.; MAEDA, S.; VITORINO, A.C.T.; GONÇALVES, M.C. \& MARCHETTI, M.E. Determinação de teores ótimos de nutrientes em soja pelos métodos chance matemática, sistema integrado de diagnose e recomendação e diagnose da composição nutricional. R. Bras. Ci. Solo, 31:63-72, 2007.

van KEMPEM, T. \& J ACKSON, D. NIRS may provide rapid evaluation of amino acids. Feedstuffs, 2:12-15, 1996.

WADT, P.G.S. Os métodos da chance matemática e do sistema integrado de diagnose e recomendação (DRIS) na avaliação do estado nutricional de plantios de eucalipto. Viçosa, MG, Universidade Federal de Viçosa, 1996. 123p. (Tese de Doutorado)

WILSON, R. Seed composition. In: STEWART, B.A. \& NIELSEN, D.R., eds. Soybeans: I mprovement, production and uses. 3.ed. Madison, ASSA/CSSA/SSSA, 2004. p.621677. (Agronomy Monograph, 16) 